Heimbeck, Lovise S. 1954. On the etiology of brown roots. Yellowing and wilt due to " $\mathrm{B}$ type (Dienes) L. (Kleinberger) forms" of bacteria, with special reference to pea wilt. Oslo. Published by author.

McClintock, Barbara. 1939. The behaviour in successive nuclear divisions of a chromosome broken at meiosis. Proc. National Acad. Sci. (U.S.) 25: 405-416.

RAPER, K. B., AND C. Thom. 1941. Interspecific mixtures in the Dictyosteliaceae. Amer. Jour. Bot. 28: 69-78.

Skupienski, F. X. 1920. Reserches sur le cycle évolutif des certains myxomycetes. Paris. Published by author.

Straus, J. 1954. Maize endosperm tissue grown in vitro. II. Morphology and cytology. Amer. Jour. Bot. 41 : 833-839.
Sussman, M. 1955. Developmental physiology of the amoeboid slime molds. In Biochemistry and physiology of protozoa. Vol. II, 201-223. Academic Press. New York.

1956. The biology of the cellular slime molds. Ann. Rev. Microbiol. 10: 21-50.

Wilson, C. M. 1952a. Sexuality in the Acrasiales. Proc. National Acad. Sci. (U.S.) 38: 659-662.

1952b. Meiosis in Allomyces. Bull. Torrey Bot. Club 79: 139-160.

1953. Cytological study of the life cycle of Dic tyostelium. Amer. Jour. Bot. 40: 714-718.

, AND I. K. Ross. 1955. Meiosis in the myxomycetes. Amer. Jour. Bot. 42: 743-749.

\title{
TETRAXYLOPTERIS SCHMIDTII GEN. ET SP. NOV., A PROBABLE PTERIDOSPERM PRECURSOR FROM THE DEVONIAN OF NEW YORK ${ }^{1}$
}

\author{
Charles B. Beck
}

IN EASTERN New York, Devonian strata have yielded large, well-preserved plant compressions from which a relatively complete knowledge of the external form of the plants has been obtained. Generally, nothing has been discovered about the internal anatomy of these plants. A source of valuable information which has been largely neglected is the pyrite petrifaction occurring occasionally in direct association with the compressions. Many of the fossil specimens on which this study is based are compressions with segments of some axes structurally preserved in pyrite. This paper describes an Upper Devonian plant from eastern New York giving details of both internal and external structure.

Materials and Localities.-The material on which this work is based was collected from Upper Devonian strata at two localities in New York: (1) the Oneonta formation in Davidson Quarry near Davenport Center, Delaware County, and (2) the Delaware River sandstone exposed in a road cut at Hawk's Nest on New York State route 97 near Port Jervis, Sullivan County. The Davidson Quarry material, collected by Dr. Victor Schmidt of Brockport State Teachers' College, contains both compressions and associated pyrite petrifactions. For this reason it is the more valuable material. Because of the coarseness of the sand-

1 This paper is taken from a thesis presented to the Graduate School of Cornell University in partial fulfillment of the requirements for the Ph.D. degree. The writer expresses appreciation to Professor H. P. Banks of the Department of Botany for his genuine interest and able guidance during the course of this work and for suggestions regarding the preparation of the manuscript.

The writer also acknowledges with appreciation the suggestions made by Professor John Walton of the University, Glasgow in whose department the manscript was prepared; and those made by Professors Suzanne Leclercq, Université de Liége and Chester A. Arnold, University of Michigan. stone and the friable nature of the plant material the finer axes are however rarely found intact or well-preserved. The Hawk's Nest material was collected by Prof. H. P. Banks. This material of only well-preserved compressions has supplied valuable corroborative information about external mor. phology.

According to Chadwick (1935) and Cooper et al. (1942) the Oneonta formation is correlated with the Cashaqua and Middlesex shales of the Genessee Valley and the Ithaca formation of the Cayuga Lake Region. In southeastern New York and northeastern Pennsylvania the Delaware River sandstone is the equivalent of at least the upper portion or possibly the entire Oneonta formation according to Willard $(1936,1939)$. These formations comprise the lower part of the Naples Group of the Finger Lakes Stage.

Technigues.-The greatest technical problem encountered was that of preparing the small sections of pyritized axes for microscopic examination. Since pyrite is opaque it must be examined with reflected light. Great difficulty is usually encountered in obtaining polished surfaces of such sections because of the tendency for cut surfaces to crumble during grinding and polishing. This tendency is intensified if a large amount of carbonaceous wall material is present. Pyrite oxidizes rapidly when exposed to the atmosphere which also causes crumbling. These difficulties were overcome by the use of an embedding technique described in detail in a previous paper (Beck, 1955). More than 200 sections of the pyritized axes were successfully prepared.

In attempts to isolate spores and cuticular remains several maceration techniques were used without success. The transfer technique of Walton (1923) was used with limited success and some 
valuable information about ultimate divisions and sporangia was gained.

DESCRIPTION OF PLANT.-Vegetative portions.The preserved portions consist of axes considered to be stems to which are attached complex, radially symmetrical branch systems of monopodial axes with lateral branches of several orders. The branch systems are arranged on the stem in a crowded spiral (fig. 1). No expanded blade-like structures recognizable as leaves are present. However, it is not unlikely that these branch systems attached to the stem are homologous with leaves. They will be referred to subsequently as fronds. To facilitate their description the following terminology will be used. The term rachis will designate an axis which usually gives rise to three orders of lesser axes and which is assumed to be the main axis of the frond. The lesser axes will be desig. nated in decreasing order $\mathrm{r}+1, \mathrm{r}+2$ and ultimate divisions. These axes branch in an opposite or sub-opposite manner (fig. 1-4) with succeeding pairs in planes at right angles, i.e., 4-ranked. Their arrangement is therefore quite unlike the spiral attachment of rachises to the stem.

- The largest stem fragment found measures about $2.5 \mathrm{~cm}$. in width and $24 \mathrm{~cm}$. in length. There is evidence from both internal anatomy and external morphology that the stem branched sympodially or nearly dichotomously. One axis examined shows a cross-section of the stem at a point of branching in which there are two large masses of xylem of unequal size indicating a pseudomopodial or sympodial branching. The writer has seen some compressed axes in the quarry at Davenport Center which measure up to $8 \mathrm{~cm}$. in width and $0.5 \mathrm{~m}$. in length. Though it has been impossible to make any positive identification of these axes it is pos. sible that they are larger basal portions of the stem of the plant under consideration. If so, it is likely that this plant attained the size of a small tree as much as $3 \mathrm{~m}$. in height.

Although definite information on the size and gross structure of the plant is lacking, details of the structure of the fronds, both anatomical and morphological, are well known. In overall size they attained a length of $30 \mathrm{~cm}$. or more and because of the repeated opposite and decussate branching they produced a dense, bushy appearance. The distance between the position of rachises on the stem and their size varies considerably. Comparable lesser axes $(r+1, r+2)$ of differ. ent specimens also vary in size and spatial relationship. Such differences are apparently the result of variation in the age and maturity of these plant parts. All axes constituting the fronds are covered by a system of very fine longitudinal ridges which appear to represent rows of cells. Whether the system of ridges actually represents the epidermal pattern is uncertain since no cuticular remains have been obtained.

Little doubt remains concerning the pattern of branching of the fronds. An excellent series of sections was obtained from an $\mathbf{r}+1$ axis. An examination of photographs of two of these sections (fig. 19, 20) and the camera lucida drawings of the entire series (fig. 2lA-H) provides proof that the $r+2$ axes leave the $r+1$ axes in nearly opposite pairs and that successive pairs are in planes at right angles. Evidence that the ultimate divisions also occur in a decussate arrangement is given by these photographs and drawings.

The decussate arrangement of the $r+1$ axes on the rachis cannot be fully substantiated by anatomical evidence at present although the cruciform shape of the primary xylem strand, identical with that of the $\mathrm{r}+1$ axes, is indicative of this type of branching. By careful chipping of the compression specimens it becomes quite clear that all branching within the fronds is opposite or sub. opposite.

To demonstrate convincingly the radial symmetry of the fronds on the basis of compressions alone is difficult. On a relatively smooth surface of a slab of rock the specimens often appear to be bilaterally symmetrical, but in many cases the chipping away of successive thin layers of rock shows that the radially symmetrical plant has been greatly compressed by the weight of coarse sediment and only appears to be in one plane. When such compression has been at a minimum an irregular, diagonal break of the rock exposes the radial symmetry beautifully. In some cases, even on a relatively flat surface, very careful examination of the angle of departure of pairs of opposite axes also gives evidence that they are in alternating planes. This type of evidence cannot unfortunately be illustrated by photographs.

On the basis of compression specimens alone one might assume that all axes of the fronds were more or less terete. There is good evidence from anatomical study that the $r+2$ axes and the distal part of the $\mathbf{r}+1$ axes are distinctly fourlobed, exhibiting a clover-leaf shape in transverse outline as shown diagrammatically in fig. 32 . Evidence for this in $r+1$ axes is shown in fig. 21C-G in which the $v$-shaped indentations (drawn as dotted lines) represent preserved portions of the epidermis which when connected would give a lobed configuration. The outermost solid line represents the limits of the pyrite in which the plant is preserved. The basal portions of the $r+1$ axes might also be somewhat four-lobed since the secondary xylem retains a four-lobed configuration (fig. 13). The extent of lobing apparently decreases basipetally as the amount of secondary xylem increases. Figure 16 shows an $r+2$ axis not quite free from the $r+1$ axis with three external lobes formed even before its trace has separated from the $r+1$ xylem strand.

The ultimate divisions are of considerable interest. They are similar to those found in some other Devonian plant's such as Aneurophyton, Rhacho- 


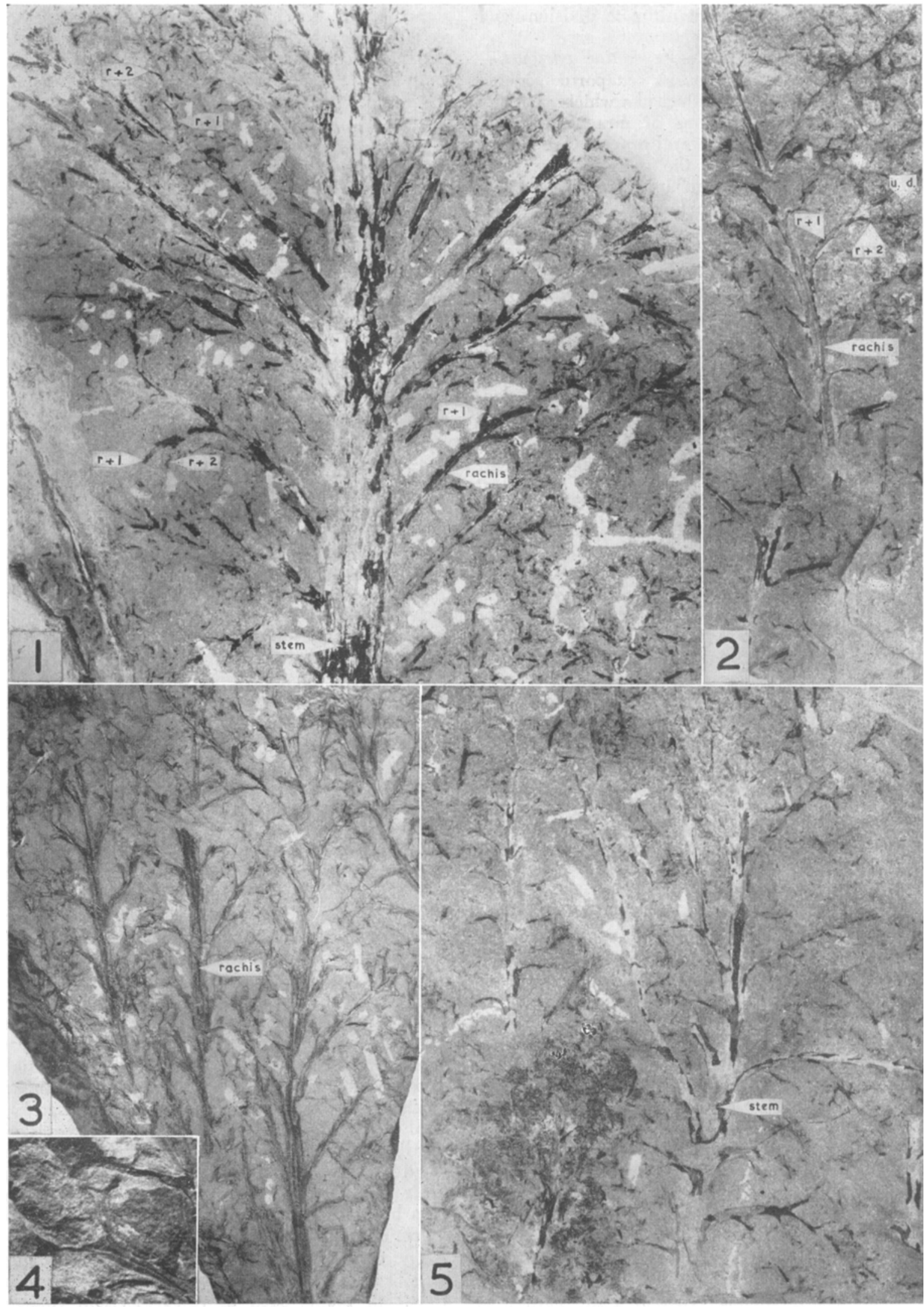


phyton, etc. They consist of short axes which bear one or two terminal dichotomies, the segments of which are often recurved (fig. 4,6). The segments vary in width from about 0.4 to $0.9 \mathrm{~mm}$. A width of about $0.7 \mathrm{~mm}$. is common. The distance between their tips varies from about 2.0 to $4.5 \mathrm{~mm}$. Drawings $C, D$ of fig. 21 show succeeding pairs of sub-opposite traces to the ultimate divisions occurring in planes at right angles indicating that the branching pattern is identical with that in other parts of the fronds.

It seems to have been generally considered that ultimate divisions in other genera are flattened structures. The ultimate divisions of this plant are flattened by compression like the other axes, but one would not conclude from the compressions alone that all of the plant axes were thin and flattened in life. The writer suggests that possibly in the living plant the ultimate divisions were terete. Evidence suggesting this is illustrated in fig. $21 \mathrm{H}$ which shows that at least the basal portion of the ultimate divisions was probably not flattened.

On the basis of the evidence presented in the foregoing section the writer has made a pictorial reconstruction of the vegetative portions of this plant. Figure 32 shows a stem from which arise in a spiral the fronds with their decussate branching. The transverse configuration of the various axes has been emphasized by diagrams of transverse sections.

Fertile portions.-Information about the fertile fronds is incomplete and the following description must be considered tentative and necessarily somewhat speculative in part. It seems quite possible on the basis of information gained from the material at hand that there are some important differences between the fertile fronds and those of strictly sterile or vegetative nature. Of considerable importance is the fact that the fertile fronds are only partly fertile. The sporangia are produced in the apical region of fronds which are vegetative in their basal portions (fig. 7,8 ). As far as can be determined, the branching pattern of the basal vegetative portion is identical with that of the sterile fronds. Careful examination has convinced the writer that the apical fertile portion of the fertile fronds is probably also radially symmetrical and differs only in a possible 2-ranked arrangement of the $r+2$ axes.

There is no doubt that the arrangement on the rachis of the $\mathbf{r}+1$ axes is opposite in both the basal (sterile) (fig. 7,8) and apical (fertile) (fig. 9,12 ) portions of fertile fronds. Careful examination of the specimens has convinced the writer that these axes are also decussately arranged in both regions. The only petrified axis from a fertile

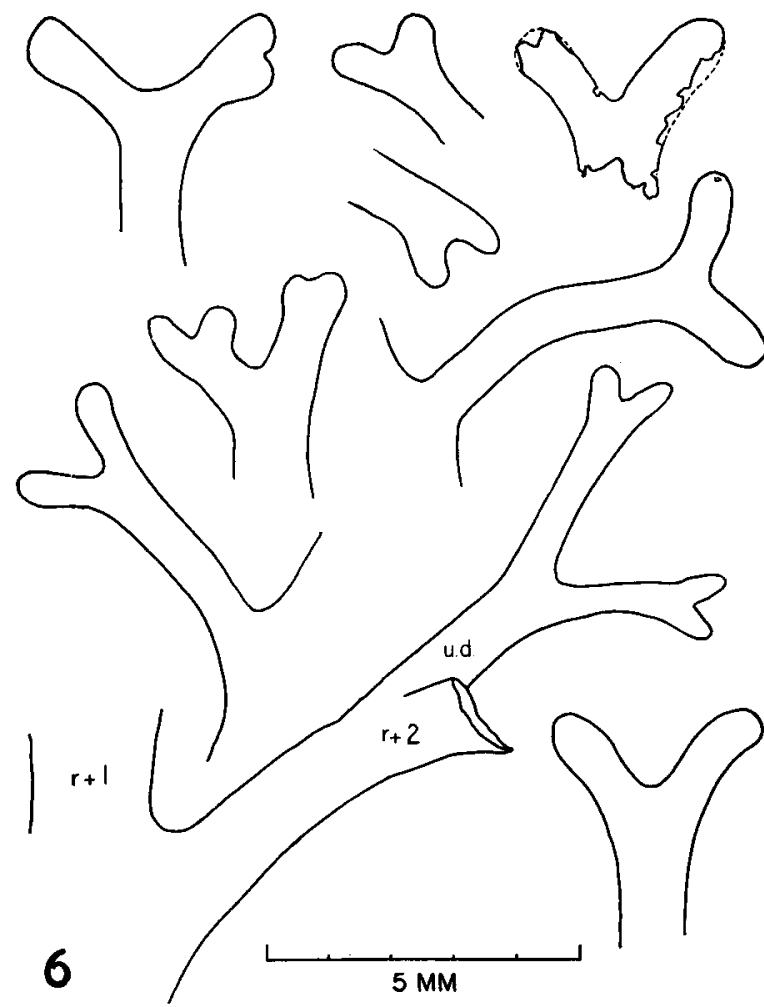

Fig. 6. Camera lucida drawings of ultimate divisions of Tetraxylopteris.

frond (fig. 11) was secured from the rachis of a fertile part (fig. 12,a). Its primary xylem strand, though cruciform like the strands in sterile rachises, has two arms which are considerably larger than the others. This condition might suggest that only the two large arms gave rise to traces and consequently that the $r+1$ axes in this part of the frond were 2-ranked. Unfortunately too little axis was preserved to show traces. Because the two smaller arms seem simply to be poorly preserved, and in view of the evidence from external morphology this possibility has been discounted, at least for the present.

In the fertile region the $r+2$ axes arise from the $\mathrm{r}+\mathrm{l}$ axes in opposite or sub-opposite pairs (fig. 10). They seem to be attached only on the adaxial side of the $\mathbf{r}+1$ axes indicating that they are two-ranked (fig. 7, 8).

The sporangia are borne on the $r+2$ axes and seem to be attached to the side facing the rachis. They thus often appear more or less at right angles to the rachis (fig. 7-9). Because of the fact that the sporangia usually occur in dense masses which obscure the branching pattern it has been impos.

Fig. 1-5. Tetraxylopteris schmidtii.-Fig. 1. Large stem fragment bearing spirally arranged fronds. $\times 7 / 10 .-F i g .2$. Fragment of a sterile frond. $u . d .=$ ultimate division. $\times 7 / 10 .-$ Fig. 3 . Fragments of three sterile fronds from the Hawk's Nest locality. $\times 7 / 10 .-$ Fig. 4. An ultimate division. $\times 1 \frac{1}{2}-$ Fig. 5 . Slab containing the terminal portion of a stem, a fragment of a fertile frond and a fragment of a sterile frond. $\times 7 / 10$. 


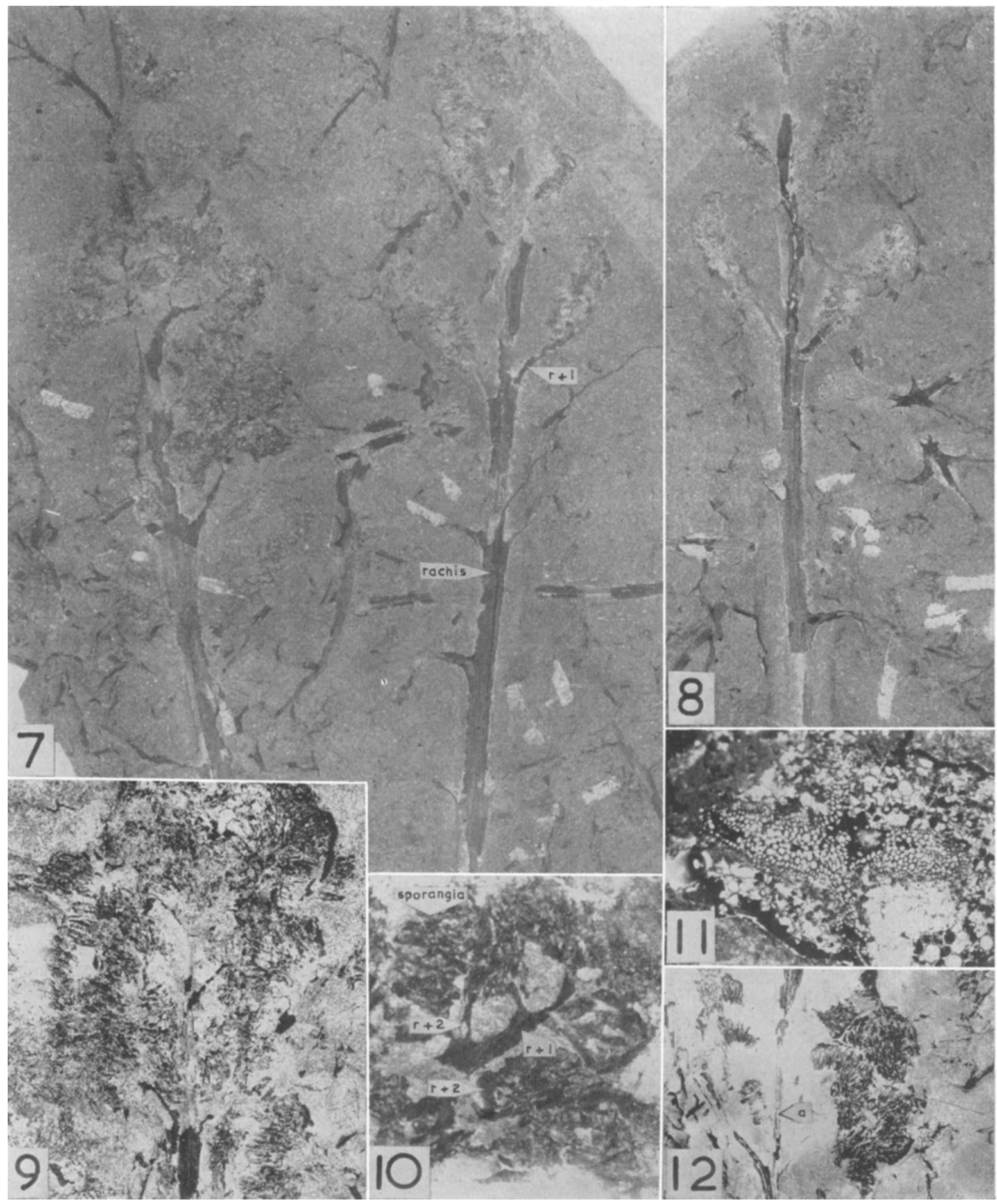

Fig. 7-12. Tetraxylopteris schmidtii.-Fig. 7. Two fragmonts of fertile fronds. Note that the sporangia are restricted to the apical region and are borne on the $r+1$ axes. $\times 9 / 10 .-F i g .8$. The counterpart of the fertile trond suown on the right in fig. 7. A study of part and counterpart gives definite indication of the opposite arrangement of the fertile $\mathbf{r}+1$ axes. $\times 9 / 10$. -Fig. 9. Sporangiferous portion of a fertile frond showing sporangia oriented at right angles to the rachis. $\times 1 \frac{1}{2}$. - Fig. 10. Small fragment from a fertile frond showing some details of branching. $\times 37 / 10 .-F i g .11$. Transverse section of the rachis of a fertile frond from th? specimen shown in figure 12 at $a$. $\times 33$. - Fig. 12. Fragment of a fertile frond. $\times 11 / 10$. 
sible to determine with complete certainty details of the finer structure of these fertile portions, and the exact manner in which the sporangia are attached to the $r+2$ axes is unknown. On the basis of the available evidence it is likely that they were either attached by a very short stalk or were sessile (fig. 10). The sporangia are ovoid-elongate with an acute base and apex and are $2.5-5.0 \mathrm{~mm}$. long and $0.5-0.8 \mathrm{~mm}$. wide. The surface is marked by fine longitudinal ridges like those of the vegetative portions. Since no specialized means of dehiscence has been observed it is assumed that they are exannulate. Information about spores is lacking. Because of the occurrence of one size only, the terminal position and the possible exannulate condition of the large sporangia, it is the opinion of the writer that the plant was probably homosporous.

ANatomy.-Both primary and secondary tissues are beautifully preserved in many portions of pyritized axes. The information gained from a study of these tissues, which is of considerable value for its own sake, is even more important because it has aided in the interpretation of the external form of the plant.

In the following description all measurements given were obtained in as objective a manner as possible. Whenever possible, 25 measurements were taken. To make the measurements as random as possible, all cells of a type were measured along a tangent in the tissue. When several well-preserved specimens were available, measurements were taken from all specimens. The minimum, mean and maximum values given below were then obtained from these 25 measurements.

Primary tissues.-Primary xylem.-No specimens believed to be stem have been found in which the central portion is well enough preserved to determine conclusively the configuration of the primary xylem. However, there is good evidence on the basis of a series of slides that no pith exists and that the strand is protostelic like that of other portions of the plant.

The primary xylem strand in the fronds is cruciform in shape (fig. 13, 14, 17-21). The strand in the rachis is probably identical with that of the $r+l$ axes. Although only partly preserved strands have been found, several sections from a rachis give good indication of the similarity. In $\mathrm{r}+1$ axes the four arms are slender with more or less parallel sides and of approximately equal length (fig. 13, 14, 19-21). Near points of trace departure the arms contributing the traces become slightly more elongate and the ends become enlarged (fig. 14, 15, 21D). In the $\mathrm{r}+2$ axes the primary xylem strand though basically tetrarch is of somewhat different shape from that found in the larger axes of the plant. The four short arms arise from a thick central portion and taper abruptly (fig. 17, 18). In other $r+2$ axes the arms may be hardly distinguishable and the strand then appears more or less diamond-shaped (fig. 19, 20, $21 C, F, G)$. The long axis of these strands is in the plane of departure of the traces. Figures 16 and 17 show the origin of the xylem strand in an $\mathrm{r}+2$ axis. The strand forms the characteristic cruciform shape shortly after becoming free from the arm of the parent strand (fig. 17). The size of the xylem strand in the $\mathrm{r}+1$ axes is remarkably uniform. Measurements of the distance between the tips of opposite arms vary from 1.33-1.8 $\mathrm{mm}$. with a mean value of $1.6 \mathrm{~mm}$. The mean distance along two arms of an $r+2$ strand, on the other hand, is only $0.64 \mathrm{~mm}$. The extremes of variation in the $r+2$ strands are considerably greater, however, ranging from 0.4 to $1.5 \mathrm{~mm}$. The primary xylem strand in the base of the ultimate divisions no longer retains the cruciform shape of the strands of larger axes and is terete (fig. 20, 21G, $H$ ).

The order of maturation of the protoxylem is mesarch (fig. 15). Conspicuous protoxylems usu. ally occur near or at the ends of the arms of the primary xylem strand (fig. 14, 15, 17, 18). In strands of the $r+1$ axes each arm has at least one internal protoxylem located more or less centrally in the arm or toward its base (fig. 15, $21 A-G$ ) and in many cases there is a protoxylem at the center of the strand (fig. $21 A-G$ ). In strands of the $r+2$ axes there are fewer internal protoxylems. In some cases there is a single central protoxylem and peripheral protoxylems may be apparent only at the ends of arms from which traces are about to depart. The protoxylem elements are small and irregularly angular in transverse outline (fig. 15). They measure $13 \mu$ in approximate mean width. Their length and details of pitting or other secondary wall characteristics are unknown. The metaxylem consists of larger and irregularly angular elements usually $4-6$-sided in transverse outline (fig. 15). They vary in width from about

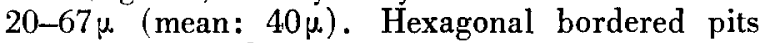
occur on all walls.

Primary phloem.-The primary phloem has been observed only rarely and when preserved at all is badly crushed and distorted. It appears to consist of a relatively uniform tissue of thin-walled parenchymatous cells which completely surrounds the primary xylem strand (fig. 15). The primary phloem was not observed in longitudinal section. Pericycle and endodermis were not observed.

Cortex.- The cortex consists of two distinct regions, a relatively wide inner cortex and a narrow outer cortex. The inner cortex (fig. 14, 22) is a heterogeneous tissue composed of large, oval cells, thin- to relatively thick-walled and parenchymatous in appearance, scattered among which occur a few fibers. The fibers occur primarily in the innermost region of the inner cortex, and it is possible that they are part of the first-formed secondary phloem. The large parenchymatous cells 


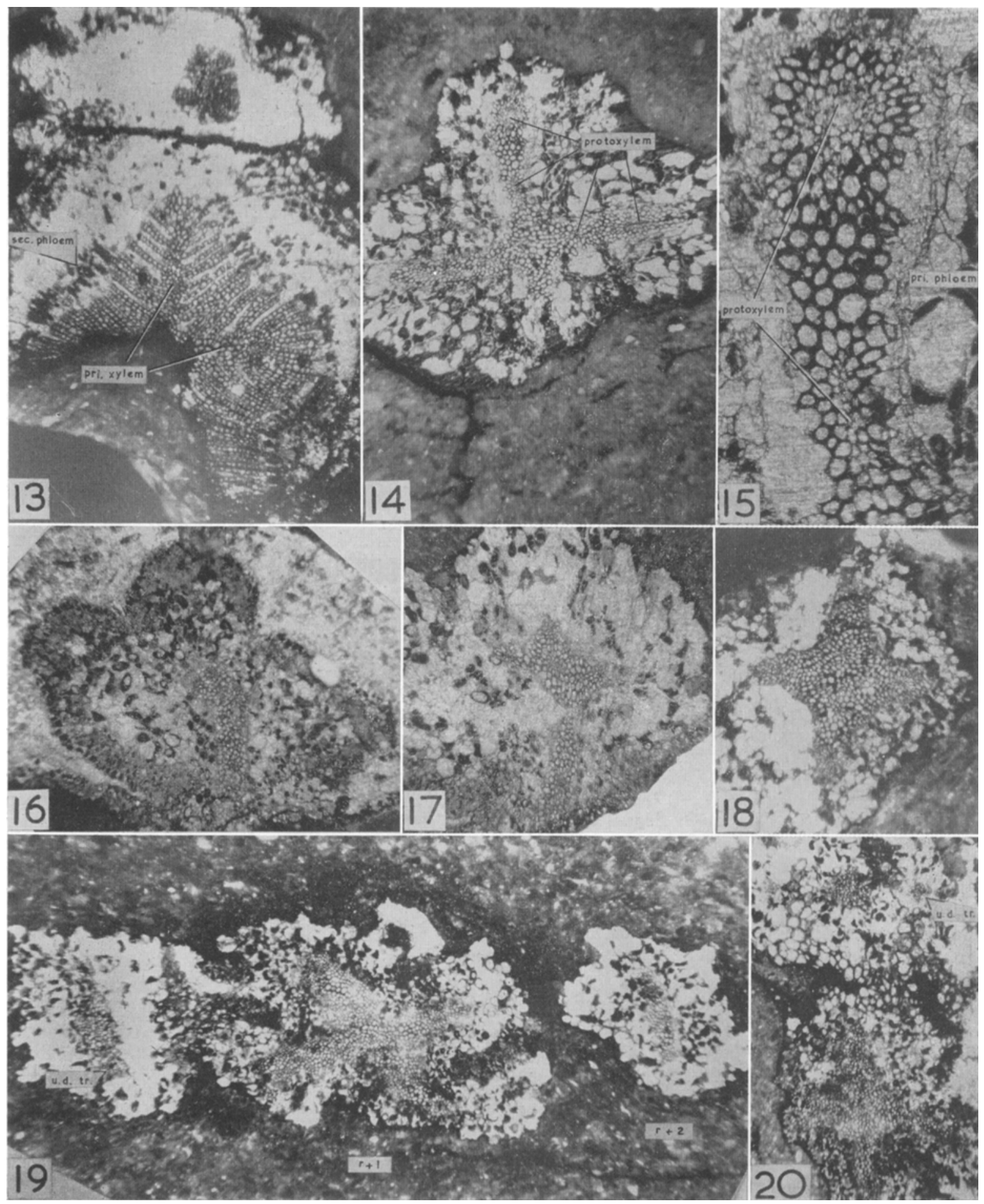

Fig. 13 20. Tetraxylopteris schmidtii.-Fig. 13. Transverse section from the basal region of an $r+1$ axis. Note also the $r+2$ axis with secondary xylem. Slide No. 1187E d(2). $\times 28$. Fig. 14. Transverse section from an $r+1$ axis. Note cortex and cruciform primary xylem strand with mesarch protoxylems. Slide No. 1187A 7c. $\times 30 .-$ Fig. 15 . Enlargement of one arm of the primary xylem strand shown in fig. 14. X118.-Fig. 16, 17. Serial transverse sections showing the formation of an $r+2$ axis.-Fig. 16. Note that 3 external lobes are apparent before the $r+2$ axis is free from the $\mathrm{r}+1$ axis; also the sclerenchymatous appearance of the outer cortex. Slide No. 1187E $\mathrm{k}(1)$. $\times 35 .-$ Fig. 17. Note that the cruciform shape of the $r+2$ primary xylem strand is reconstituted shortly after becoming free from the $\mathrm{r}+1$ strand. Slide No. 1187E $\mathrm{k}(2)$. $\times 35 .-$ Fig. 18. Transverse section of an unusually large $\mathbf{r}+2$ axis. 
range in diameter from about $39-146 \mu$ (mean: $81 \mu)$. The fibers have a mean diameter of $44 \mu$.

The outer cortex, although rarely preserved, was discovered in an excellent state of preservation in one specimen. It is composed of a homogeneous. probably sclerenchymatous tissue 3 to 4 cells in width. The cells are thick-walled, and in transverse section look somewhat like fibers (fig. 16. 31). Judging from their relatively large size and large lumens they might have been thick-walled parenchyma. They range in diameter from $28-67 \mu$. (mean: $53 \mu$ ). They have not been observed in longitudinal section.

Epidermis.-Portions of the epidermis have been found preserved in several sections. The cells are thick-walled, square to rectangular and seem to be basically 4-sided in transverse section. They are relatively large with an approximate mean width of $50 \mu$. There is evidence of one to several periclinal divisions, probably originating in the epidermis, indicating the beginning of periderm formation (fig. 31).

Traces. - Study of the origin and departure of traces has been of importance as an aid in interpreting the pattern of branching in the fronds, and general reference to the traces has been made previously in the description of the vegetative portions of the plant. Most of the information on which the following discussion is based was obtained from a series of serial sections, two of which are illustrated by photographs in fig. 19 and 20. Since little detail of protoxylems is visible in these photographs reference will be made only to the camera lucida drawing of the entire series (fig. $21 \vec{A}-H$ ).

The primary xylem strand in the $\mathrm{r}+1$ axes in this series usually seems to contain nine protoxy. lems. Where less than nine are shown this is due to lack of preservation or poor preservation of part of the strand. There are two protoxylems in each arm, one near the end and one near the center or base of the arm. The odd or ninth protoxylem occurs in the center of the strand and seems to supply new protoxylems to the arms as traces depart.

From an examination of fig. 19 and $21 A-H$ it is obvious that traces depart from opposite arms of the primary xylem strand at nearly the same level and are slightly sub-opposite. This is true not only of traces which supply $\mathrm{r}+2$ axes but also of those to the ultimate divisions.

Protoxylems about to depart as traces are very conspicuous and the ends of the arms of primary xylem are somewhat enlarged (fig. 15, 21D, G). The outermost protoxylems in the other two arms from which traces have recently departed are farther from the end of the arms and are oval or elongate in shape (fig. $21 A, F$ ). When the ter-

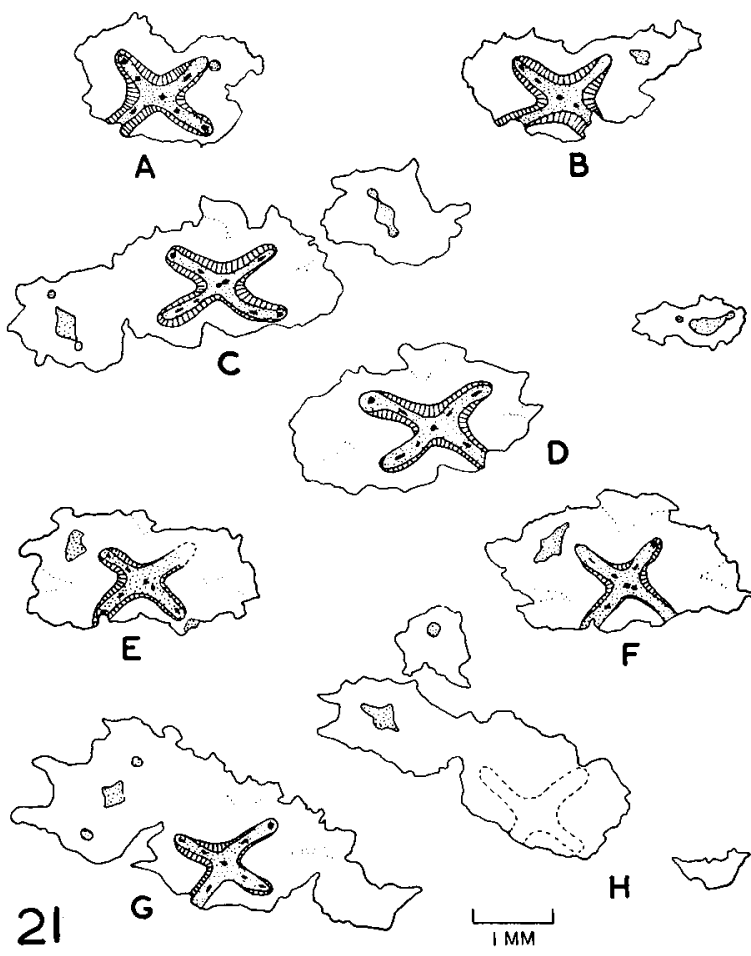

Fig. 21A-H. Camera lucida drawings of serial sections from an $\mathrm{r}+1$ axis showing the decussate branching of $r+2$ axes and ultimate divisions. Compare fig. 21C and $19 ; 21 \mathrm{G}$ and 20 . Note also the change in position of the protoxylems. Stippled area $=$ metaxylem, solid black $=$ protoxylem, lined $=$ secondary xylem, dotted line $=$ epidermis, outer continuous line $=$ limit of pyrite. Further explanation in the text.

minal protoxylem moves out as a trace it is replaced by the internal protoxylem in the arm. This is replaced in turn by a branch from the protoxylem at the center of the primary xylem strand. In successively higher sections these new protoxylems are found farther and farther out in the arm (fig. $21 A-G$ ).

It must not be assumed that nine protoxylems is characteristic of the xylem strands of all $r+1$ axes. The number varies and probably depends on the position in the axis from which the sections were taken.

As might be expected in a branch system in which the form of the primary xylem strand is repeated in successive orders of branching, traces from axes with relatively large amounts of secondary xylem are also accompanied by secondary xylem (fig. 13).

SECONDARY TISSUEs.-Both secondary xylem and secondary phloem occur in the stem, the rachis of fronds, the $r+1$ axes and probably in the basal

Slide No. 1187A 5b. $\times 26$. -Fig. 19, 20. Transverse sections selected from the series of serial sections shown in fig. 2128 to illustrate the decussate branching of $r+2$ axes and ultimate divisions.-Fig. 19. Compare with fig. 23. Slide No. 1187A-S2. $\times 20 .-$ Fig. 20. Compare with fig. 27 . Slide No. $1187 \mathrm{~A}-\mathrm{S} 4 . \times 20 . u$. $d . t r$. $=$ trace to ultimate division. 
regions of some $r+2$ axes. Though periderm is believed to have been produced it has not been observed in extensive amounts. Usually the outer portion of the axis has been destroyed before preservation.

Secondary xylem.-The secondary xylem is a relatively compact tissue consisting of tracheids and abundant rays (fig. 13, 28). Definite growth layers occur with as many as five layers having been observed in one specimen. The latewood portion is narrow, consisting usually of three tangential rows of cells. The radial rows of tracheids abut on the arms of the primary xylem strand at nearly right angles (fig. 13).

The tracheids are square, rectangular, pentagonal or hexagonal in transverse section (fig. 28). They are widest in radial dimension except in latewood regions where their greatest width is usually tangential. In radial width they range from $26-$ $113 \mu$ (mean: $57 \mu$ ). A width of about $66 \mu$ is common. In tangential width they are 33-80 $\mu$. (mean: $54 \mu$ ). Although it has been impossible to measure the entire length of a single tracheid, they are extremely long judging from the fact that a portion of one tracheid is $2859 \mu$ long.

The tracheids are pitted on all walls, but the pits on the tangential walls are usually less numerous and slightly smaller than those of the radial walls. Otherwise they are similar. The following description applies to pits of the radial walls unless otherwise stated.

The pits are circular-bordered and alternate, usually hexagonal and crowded like so-called araucarian pits (fig. 26), but there are occasional areas in which they are not contiguous and thus not angular. In such cases they tend to lose the alternate arrangement and to become nearly opposite. The pit apertures are nearly horizontal to diagonal slits (fig. 26, 27). In no cases have crossed apertures been noted. The pits are $1-6$ seriate, the number of rows probably depending on the width of the tracheid since the pits are very uniform in size on a given wall. The pits on the radial walls range in width from $13-17 \mu$ with a width of $15 \mu$ common. Tangential pits are smaller with a width of from about 9-11 $\mu$.

The rays are numerous, uniseriate to multiseriate and of varying height. In the first-formed secondary xylem of several specimens many of the rays are completely multiseriate giving the wood a manoxylic appearance (fig. 13). The older wood has a more compact or pycnoxylic appearance, but when examined carefully is found to contain some rays with bi- or multiseriate portions. Rays which seem to be basically uniseriate frequently become dilated and multiseriate at the periphery of the secondary xylem. In radial section the rays are seen to consist of horizontal rows of more or less rectangular cells (fig. 29). Although it has been impossible to measure the total height of any ray, there seems to be considerable variation from relatively low to relatively high rays. The highest portion of a ray observed consisted of 27 rows of cells.

All cells observed in the rays are parenchymatous. The ray cells tend to be rectangular in radial view with their long axis oriented horizontally. The ends may be square, tapering or slanted (fig. 29). They are from 26 to $67 \mu$ (mean: $47 \mu$ ) high. In length they vary from 46 to $146 \mu$ (mean: $94 \mu$ ). The wood, though diffused with abundant ray parenchyma, is nevertheless of such a compact nature that it probably should be considered pycnoxylic.

Secondary phloem.-Preservation of the secondary phloem is uncommonly good and several cell types can be distinguished. Their interpretation is difficult since little is known about the effect of pyritization on various tissues and cell types.

The most conspicuous cells in the secondary phloem are the fibers which are preserved in all specimens (fig. 22, 23, 30). They are very thick walled, oval to squarish in transverse outline, and occur in discontinuous radial rows, singly or in small groups scattered at random through the phloem tissue. In size these fibers range from 33 to $60 \mu$ (mean: $43 \mu$ ) in diameter. The longest portion of a fiber measured is $2262 \mu$.

A second cell type of the secondary phloem is represented by cells thought to be the main conducting elements (fig. 25, 30). They usually occur in clusters of $2-6$ or 8 cells, or occasionally in short radial rows, and although their true nature is unknown they will be called sieve cells for convenience. Although these cells have a parenchymatous appearance they have thick walls which are very irregularly thickened, thus causing the delimited inner region of the cells to be very angular in outline (fig. 25,30 ). This angularity has probably been accentuated by slight compression of the cells. The sieve cells are oval, round or polygonal in transverse outline. They are elongated longitudinally but are relatively short when compared with the fibers. Their mean diameter is $48 \mu$. It is extremely difficult to obtain an exact measurement of the length of these cells though some are longer than $865 \mu$. No sieve areas have been observed in their walls, but as only a few slides are available for study it is possible that the outer surface of the wall has not been observed. The thickness of the walls suggests that their physiological condition before preservation might have obscured sieve areas if present.

Associated with the fibers and sieve cells there are vertical columns of elongated phloem parenchyma cells with transverse end walls (fig. 24). These cells are nearly square to rectangular or irregular in transverse shape (fig. 30). They have very thin walls, appear empty, and have the general appearance of the phloem parenchyma cells of some living plants. These cells which are variable in size have a mean width of about $40 \mu$. They vary from 60 to $173 \mu$ (mean: $112 \mu$ ) in length.

There are other thin-walled parenchymatous 
cells recognizable in the phloem which are impossible to distinguish in transverse section from the so-called phloem parenchyma cells described above. In longitudinal section they are seen to be nearly isodiametric, and they might be part of the phloem rays. The phloem rays are not well-preserved in this material and are difficult to recognize in either transverse or longitudinal sections.

Periderm.-Evidence of periderm formation has already been given in the description of the epidermis. In fig. 31 there can be-seen radial rows of 2.4 cells apparently having originated in the epidermis. In the larger axes the outermost tissues have not been preserved. While the occurrence of extensive periderm tissue cannot be proven, the general anatomical makeup of the plant suggests its probable occurrence.

Tetraxylopteris gen. nov. Diagnosis.-Stems up to $2.5 \mathrm{~cm}$. in diameter or more, sympodially branched, bearing spirally arranged, radially symmetrical branch systems (fronds). Fronds consisting of a monopodial axis (rachis) bearing opposite to subopposite and decussate lateral axes of three orders, the axes of the third order being once or twice bilobed ultimate divisions. Plants with sporangia (probably exannulate) borne in the apical region only of some fronds. Abundant sporangia of only one size indicate that the plant was probably homosporous. Primary xylem strand cruciform in section in all frond axes except ultimate divisions in which it is circular; protoxylem mesarch, at ends of the arms of primary xylem, and internal.

Tetraxylopteris schmidtii sp. nov. Diagnosis. - Plants as described in the generic diagnosis. Terminal segments of ultimate divisions $0.4-0.7$ $\mathrm{mm}$. in width; distance between tips of segments varies from 2.0 to $4.5 \mathrm{~mm}$. Axes of the second order $(r+2)$ in the apical portions of fertile fronds possibly 2-ranked; sporangia borne in dense clusters, probably on short stalks; sporangia $2.5-5.0 \mathrm{~mm}$. long, $0.5-0.8 \mathrm{~mm}$. wide and spindleshaped. Primary xylem strand of rachis and axes of the first order $(r+1)$ with slender, elongate arms with parallel sides; mean distance between the ends of two arms, $1597 \mu$; primary xylem strand of $\mathrm{r}+2$ axes with short, tapering arms with a mean distance between ends of the arms of $641 \mu$. Cortex of two distinct zones, a broad inner zone of large, thin to relatively thick-walled, nearly isodiametric cells, $81 \mu$ in mean diameter, and through which may be scattered some fibers, and an outer zone of smaller thick-walled, fiber-like cells with a mean diameter of $53 \mu$. Epidermis composed of basically square to rectangular cells in transverse view with an approximate mean width of $50 \mu$. Secondary xylem consists of tracheids and rays; tracheids square, rectangular or irregular in transverse shape with mean transverse dimensions of $54 \times 57 \mu$, the radial dimension being the greater; length, over $2859 \mu$; circularbordered pits often hexagonal and crowded, in 1-6 vertical rows on the tracheid walls; pitting on all walls, but more prominent on the radial walls; pit apertures horizontal to slightly diagonal slits; rays very abundant, uniseriate to quadriseriate and up to 27 rows of cells or more in height; uniseriate rays tending to dilate and become multiseriate at periphery of secondary xylem; ray cells more or less rectangular in radial view with end walls square, tapering or slanted; mean radial dimensions $47 \times 94 \mu$ with the long axis horizontal. Secondary phloem of conspicuous fibers and parenchymatous elements; fibers $43 \mu$ in mean diameter and at least $2262 \mu$ long; possible sieve cells (sieve areas not observed) $48 \mu$ in mean diameter and up to $865 \mu$ or more in length, characterized by thick walls which are very irregularly thickened; phloem parenchyma with a mean transverse diameter of about $40 \mu$ and $112 \mu$ in length; the fibers forming radial bands, broken by clusters of sieve cells and phloem parenchyma. Phloem rays present, but inconspicuous.

Horizon.-Lower Naples Group (Oneonta red beds and Delaware River ss.).

Age.--Upper Devonian.

Types,-Holotype: specimen 2l(1187E $)^{2}$ on file in the Paleobotanical Collection, Department of Botany, Cornell University, Ithaca, New York. Paratypes: specimens 22(1187C), 23(1187C), $24(1186 \mathrm{~B}), \quad 25(1186 \mathrm{~A}), \quad 26(529), \quad 27(536)$, $28(531), \quad 29(527 b), \quad 30(527 a), 31(531)$ and $32(1187 \mathrm{C})$ on file in the Paleobotanical Collection, Department of Botany, Cornell University, Ithaca, New York.

The specific epithet is derived from the name of the collector of the holotype specimen, Dr. Victor Schmidt, of Brockport State Teachers' College, Brockport, New York.

Discussion.-The assignment of Tetraxylopteris schmidtii to a known group of plants is exceedingly difficult. It exhibits characters of both pteridosperms and coenopterid ferns. Table 1 shows the most important features of this plant which are characteristic of either one or the other of these groups, or of some members of either group. A discussion of some of these characters and a consideration of their importance in determining the taxonomic affinity of the genus follows.

The presence of extensive amounts of true secondary xylem is one of the most pteridosperm-like characters of this plant. This one character is probably sufficient in itself to separate Tetraxylopteris from the Coenopteridales. Only Botrychioxylon (Zygopteris; see Baxter, 1952) of the Coenopteridales has long been seriously considered to produce extensive secondary xylem, and today there are many who question the validity of this

2 Numbers in parentheses are collection numbers. 


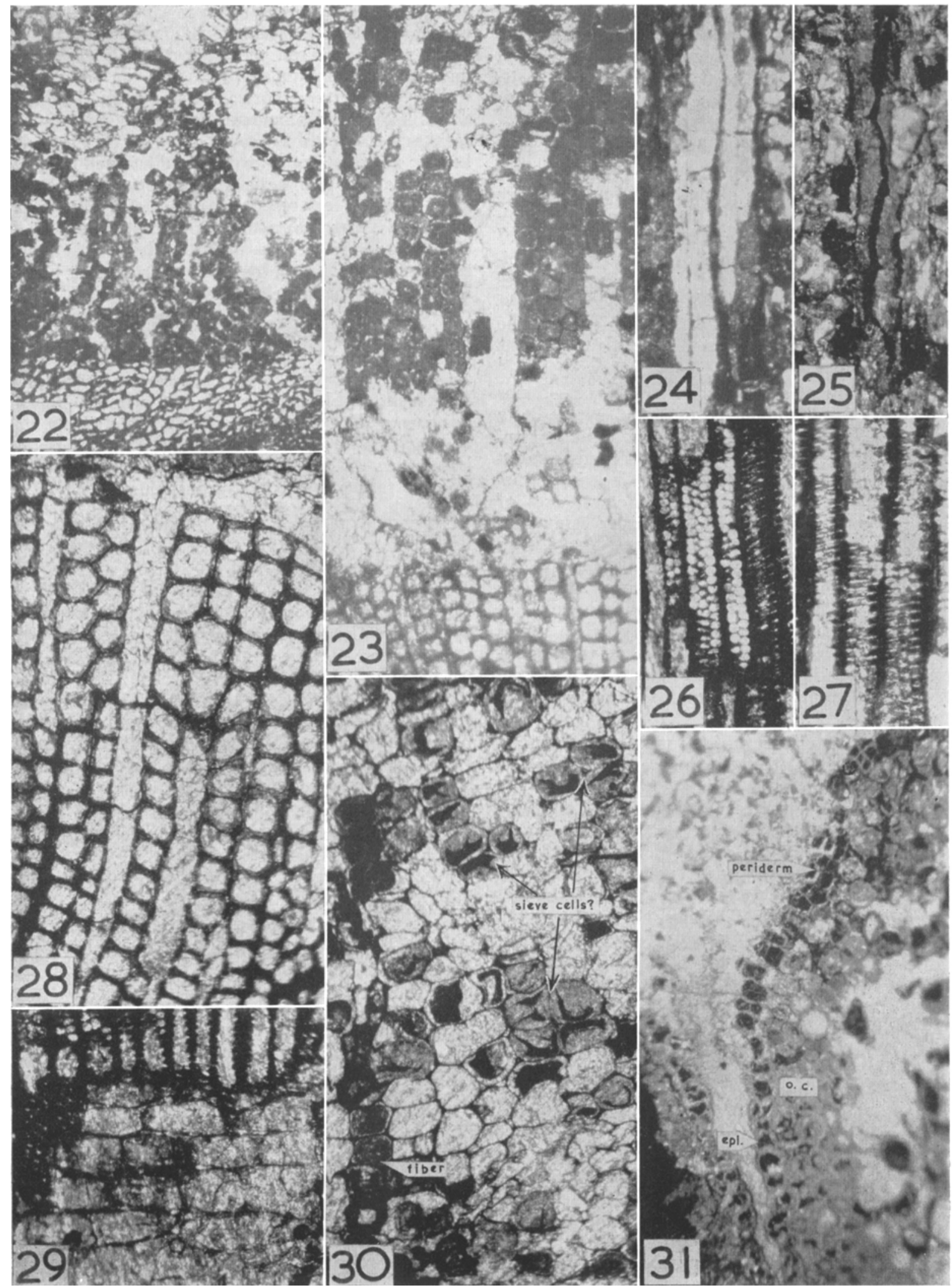


TABLe 1. A comparison of Tetraxylopteris schmidtii with the Pteridospermales and Coenopteridales. Further explana tion in the text.

TETRAXYLOPTERIS

PTERIDOSPERMALES

(including Calamopityaceae)

Secondary xylem
Secondary phloem
Occurrence of secondary xylem
in the basal portion of some
larger frond axes

Intact protoxylem elements

Sclerenchymatous outer cortex Repetition of form of primary xylem strand in various orders of branching

Radially symmetrical fronds

Large terminal sporangia

Mesearch protoxylems

Tracheids with round bordered

pits

Present
Present
Absent in fronds but accompanies leaf
traces in Lyginopteris oldhamia,
Medullosa anglica, Calamopitys ameri-
cana, etc.
Present

Present

Absent

Absent

Absent

Present in most members

Present

COENOPTERIDALES

Probably absent

Absent

Absent

Absent in many (in these, protoxylems disintegrate to form "peripheral loops.")

Absent

Absent (except in Stauropteris and in fertile fronds of Rhacophyton zygopteroides)

Possibly present in Stauropteris and some other zygopterids

Present

Present in most members

Probably absent belief. Among these are Walton (1940, p. 96) and Baxter (1952).

The extensive development of secondary phloem which contains numerous fibers also tends to discourage assignment to the Coenopteridales. The writer knows of no report of secondary phloem containing sclerenchymatous elements in any fern. fossil or living. The only living fern reported to produce a cambium is Botrychium. In reference to this plant Bower (1908) says: "A sluggish cambium . . . adds fresh tracheids to the xylem, but little or nothing to the phloem. ..."

Although no well-established pteridosperm is known with fronds containing secondary xylem, this condition in a possible forerunner of the group is suggested by the presence of secondary xylem accompanying the leaf traces in several well-known pteridosperms (see table 1).

A repetition of the form of the primary xylem strand in various orders of branching in the frond is characteristic of Tetraxylopteris, Aneurophyton and Stauropteris. Tetraxylopteris is much more similar to Aneurophyton in many characters than to Stauropteris. Several workers (Andrews, 1940; Arnold, 1940) have considered Aneurophyton to have ancestral affinity with the pteridosperms.
Although radially symmetrical fronds have in the past been generally thought to characterize the zygopterids, Sahni (1918) interpreted them as basically two-ranked, believing the superficial radial appearance to be the result of reduction. Evidence for this interpretation is the embedded "pinna-trace" found in some zygopterids. This interpretation is not considered valid, particularly for Stauropteris, by Darrah (1941), but is supported by Baxter (1952) and Leclercq (1954). There is no doubt that the fronds of Tetraxylopteris are radially symmetrical, and little doubt that those of Aneurophyton (see Leclercq, 1940) are likewise of radial symmetry. If, therefore, the fronds of the zygopterids are basically bilateral, the radial symmetry of these forms is a further basis for distinction.

Tetraxylopteris produced large, terminal sporangia of only one size indicating that it was probably homosporous. The Pteridospermales is restricted to heterosporous forms bearing seeds. Many forms known only as petrifactions however and included in the Calamopityaceae are generally considered to be pteridosperms because of structural similarities to the more completely known forms (see Arnold, 1947, p. 234). It is suspected

Fig. 22-31. Tetraxylopteris schmidtii.-Fig. 22. Transver se section showing secondary xylem, secondary phloem and cortex. Note the conspicuous phloem fibers. Slide No. 1187E h(1). ×70.-Fig. 23. Transverse section showing details of secondary phloem fibers and their arrangement in radial rows. Slide No. 1187E g(1). $\times 104 .-$ Fig. 24-30. $\times 140$. - Fig. 24. Longitudinal section of phloem parenchyma cells. Slide No. 1187A 6a.-Fig. 25. Longitudinal section of part of a supposed sieve cell. Note the irregularly thickened wall. Slide No. 1187A 6a.-Fig. 26. Longitudinal section of secondary xylem showing the outline of bordered pits on the tracheid walls; also diagonally oriented, slitlike pit apertures. Slide No. 1187A 6b.-Fig. 27. Longitudinal section of secondary xylem showing nearly horizontally oriented slit-like pit apertures. Slide No. 1187E a(1).-Fig. 28. Transverse section of secondary xylem. Slide No. 1187A 6ee.-Fig. 29. Radial section showing part of a ray. Slide No. 1187A 6b.-Fig. 30. Transverse section of the secondary phloem. Slide No. 1187A 6ee.-Fig. 31. Transverse section showing outer cortex (o. c.), epidermis (epi) and first-formed periderm. Slide No. $1187 \mathrm{E} \mathrm{k}(1) . \times 85$. 
that seed production was a feature of many of these forms, but it is equally possible that others produced only spores.

Tetraxylopteris exhibits both pteridosperm and coenopterid characters but a predominance of the former. It is the opinion of the writer that in Tetraxylopteris the evolution of the secondary tissues progressed at a much more rapid rate than the reproductive structures. The complex and obviously highly specialized secondary vascular tissues of this Upper Devonian plant, unlike those of any living or fossil fern, in addition to other characters, seem to indicate a pteridosperm affinity although the plant is clearly. at the pteridophytic level of reproduction.

A more detailed comparison of Tetraxylopteris with similar forms follows. Aphyllopteris dela. warensis (Arnold, 1939) was collected at the Hawk's Nest locality from which a part of the collection of Tetraxylopteris schmidtii was obtained. The single specimen on which Arnold's species is based was examined by the writer. It bears three small axis fragments. It was discovered by chipping that these axes, described by Arnold as bearing alternate lateral axes, do in fact, bear opposite lateral axes. In this character A. delawarensis and $T$. schmidtii are similar. However, because of the very fragmentary nature of these axes and since no other usable characters are exhibited by $A$. delawarensis, it is impossible to make a positive identification with Tetraxylopteris.

Tetraxylopteris exhibits certain important similarities to Aneurophyton (Kräusel and Weyland, 1923) and Rhacophyton zygopteroides (Leclercq, 1951). These plants bear complex branch systems which, like those of Tetraxylopteris, may be homologous with leaves. In all three the branch systems terminate in bilobed, recurved ultimate divisions. The primary xylem strand is protostelic and protoxylem occurs in mesarch bundles. The shape of the primary xylem strand is reconstituted in each succeeding order of branching, except in

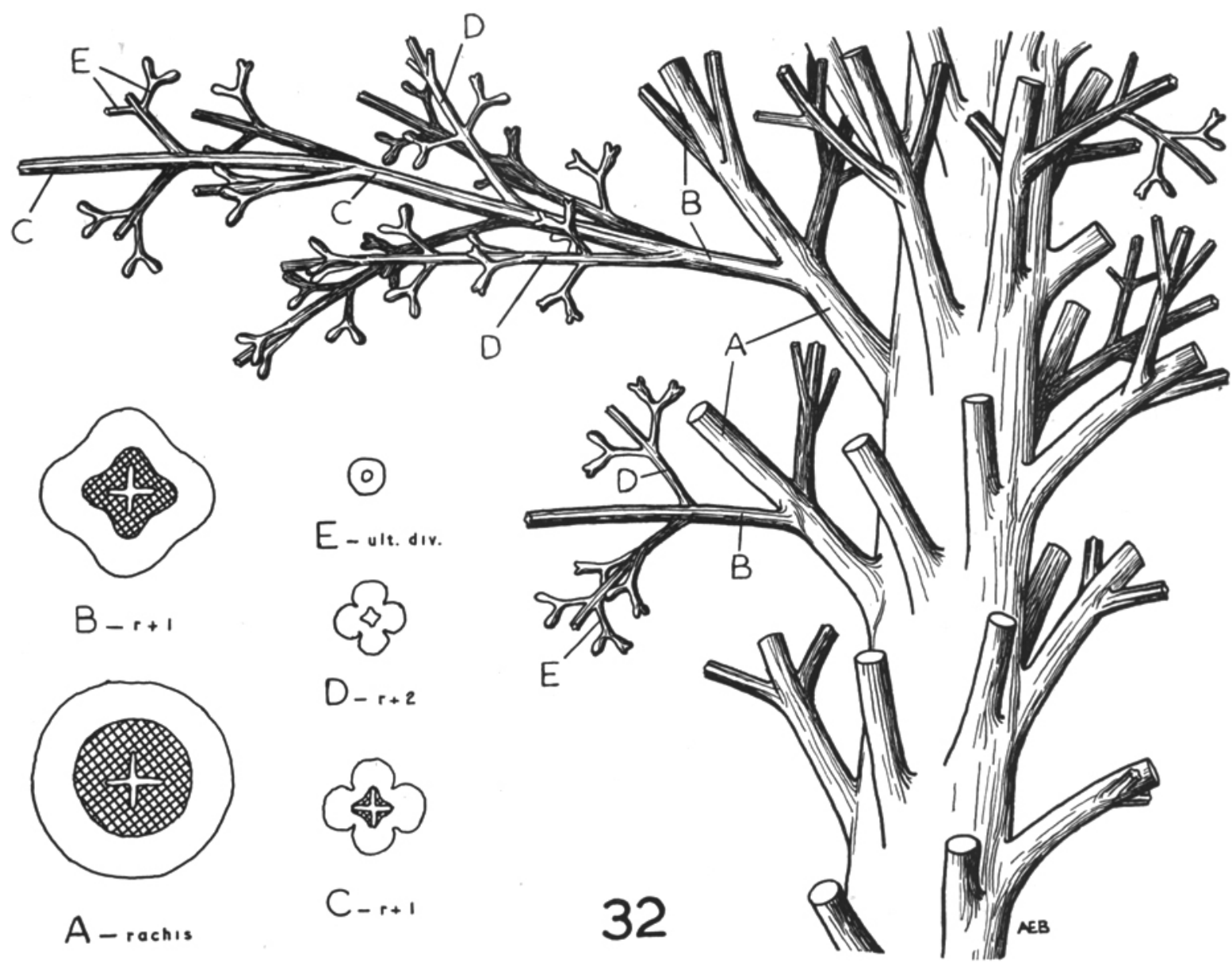

Fig. 32. Tetraxylopteris schmidtii.-A reconstruction of part of the plant showing the stem bearing sterile fronds, only the basal parts of which are illustrated. Note the decussate branching. Diagrams indicate the anatomical structure and shape in transverse section of various axes at the approximate positions indicated by corresponding letters. Reconstruction drawing by Adelaide E. Briggs under the writer's direction. 
the ultimate divisions, in both Tetraxylopteris and Aneurophyton. The secondary wood of these two forms is nearly identical in known details. All forms are thought to be homosporous, and bear relatively massive, terminal sporangia. Although these similarities exist, there are certain obvious differences by which Tetraxylopteris is easily distinguished from each other genus. Rhacophyton, placed in the Coenopteridales by Leclercq (1951), is most distinctly different. The sterile branch systems differ from those of Tetraxylopteris in that branching of the axes is alternate and tworanked whereas in Tetraxylopteris branching is decussate. Furthermore the ultimate divisions of Rhacophyton are much dichotomized (as much as 4. times), and in Tetraxylopteris they have not been observed to dichotomize more than twice. In Rhacophyton a catadromic pinnule subtends the main rachis of the branch system at its junction with the stem and there are no catadromic pinnules in Tetraxylopteris. The branching pattern in the fer. tile fronds of Rhachophyton, though of radial symmetry, is basically different from that resulting from the decussate branching of Tetraxylopteris. The sporangia of Tetraxylopteris are borne in the apical region only of the fertile fronds. Here they are distributed along the $r+1$ axes on short $\mathbf{r}+2$ axes, possibly in two ranks. This is very unlike the condition in Rhacophyton in which the sporangia are localized on pairs of catadromic pinnules which occur at the base of the pairs of primary pinnae.

A comparison of the internal anatomy of these plants further accentuates their differences. The primary xylem strand of the rachis of Rhacophy. ton is clepsydropsoid in form containing a peripheral loop at either end. This contrasts with the cruciform strand lacking peripheral loops in Tetraxylopteris. In Tetraxylopteris the cruciform shape of the xylem strand is repeated in all axes of the fronds except the ultimate divisions. No such repetition occurs in the sterile fronds of Rhacophyton, but in the fertile fronds the clepsydropsoid form of the xylem strand is repeated in the secondary order of branching.

Although similarities exist between Rhacophyton and Tetraxylopteris, they are primarily of a superficial nature. In many important characters of internal anatomy and external morphology there is a distinct contrast. It is quite obvious that these two Devonian forms are distinct from one another and their inclusion in different orders justified.

Aneurophyton more closely resembles Tetraxylopteris than does Rhacophyton although in many details of structure it is less well known. Tetraxyl. opteris is distinct from Aneurophyton in bearing fronds in which the branching is decussate, whereas branching in the latter genus is alternate. The sporangia of Tetraxylopteris vary in length from 2.5 to $5.0 \mathrm{~mm}$.; those of Aneurophyton germani- cum vary from 1.4 to $2.0 \mathrm{~mm}$. (Kräusel and Weyland, 1929). In Tetraxylopteris sporangia occur in the apical portion of fronds which are sterile at the base whereas they are apparently borne on solely fertile fronds in Aneurophyton. The 4. angled primary xylem strand of Tetraxylopteris contrasts with the 3-angled strand of Aneurophyton.

Eospermatopteris as described by Goldring (1924) is similar in several "foliage" characters to Tetraxylopteris. As a result of the work of Kräusel and Weyland (1935) there has been some difference of opinion concerning the status of Eospermatopteris, many paleobotanists, including the writer, considering it to be synonymous with the earlier named genus, Aneurophyton (Kräusel and Weyland, 1923). Consequently, no comparison of Tetraxylopteris to Eospermatopteris will be made. It must be emphasized that much of the supposed foliage and fructification remains of Aneurophyton found in eastern New York are probably Tetraxylopteris instead (see Arnold, 1947, p. 84, fig. 34; p. 87). However, Goldring's Type No. 6523 (illustrated 1924, fig. 4, p. 62) and several unfigured specimens filed under collection numbers 1599 and 1600 in the Paleobotanical Collection, New York State Museum, Albany, New York were found in the same beds with the stump casts of Eospermatopteris and are of the Aneurophyton type. The stump casts showing a reticulate surface pattern associated with Aneurophyton foliage were described first from New York (Goldring, 1924) and subsequently from Germany (Kräusel and Weyland, 1935). In neither case was there organic connection between these parts. Therefore, as suggested by Arnold (1947, p. 87), the name Eospermatopteris should be retained as an organ genus for stump casts only.

Tetraxylopteris must be compared with three other Devonian genera known only as petrifactions, Stenomyelon (see Kidston and Gwynne-Vaughan, 1912; Read, 1937), Palaeopitys (Kidston and Lang, 1923) and Sphenoxylon (Thomas, 1935). These are all axes consisting of a protostelic primary xylem strand surrounded by considerable amounts of secondary wood. All are similar to Tetraxylopteris in this respect. The known characters of the secondary xylem of Palaeopitys closely resemble those of Tetraxylopteris. The tracheids are pitted on both radial and tangential walls with multiseriate, circular-bordered pits, and the rays are probably uniseriate or multiseriate in part. Further similar features of Sphenoxylon are a 4-angled primary xylem strand ("mixed pith"), numerous mesarch protoxylems, the presence of hexagonal, circular-bordered pits on both radial and tangential walls, and the conspicuous growth layers.

Tetraxylopteris differs from each of these genera in important points. Stenomyelon contrasts in hav- 
ing exarch protoxylems, numerous broad, multiseriate rays, and pits on the radial walls only. Furthermore, the primary xylem strand is 3angled, and in $S$. tuedianum is divided by parenchyma into three sections. In $S$. muratum parenchyma is diffused throughout the strand. The lobed primary xylem strand of Tetraxylopteris dis. tinguishes it from Palaeopitys in which the strand is unlobed. Tetraxylopteris can be easily distinguished from Sphenoxylon. The solid, woody primary xylem strand of the former is unlike the parenchymatous strand of the latter. The departure of traces seems to be a basic difference. In Tetraxylopteris the trace reconstitutes its cruciform shape and gives off lateral traces whereas in Sphenoxylon the trace dichotomizes. Further differences are the lack of terminal parenchyma and branched tracheids in Tetraxylopteris, features of supposed importance in Sphenoxylon.

It is of interest to note that Tetraxylopteris, Aneurophyton, Sphenoxylon and Palaeopitys, all from the Devonian, are characterized by tracheids exhibiting bordered pits on both radial and tangential walls. In every case the pits are generally hexagonal, multiseriate, and of the circular bordered type. A Lower Carboniferous pteridosperm, Tetrastichia bupatides (Gordon, 1938). has pitting of the same type on both radial and tangential walls. This genus shows further important similarities to Tetraxylopteris. The primary xylem strand in the stem of Tetrastichia which is 4-lobed with mesarch protoxylems is very similar in appearance to that of the $\mathrm{r}+1$ axes in Tetraxylopteris. Furthermore, the secondary xylem is formed in an identical manner to that in Tetraxylopteris with the rows of tracheids mostly at right angles to the arms of primary xylem. The anatomical structure seen in a cross-section of the stem of Tetrastichia (see Gordon, 1938, plate VI, fig. 42-44) could easily be mistaken for that of an $r+1$ axis of a frond of Tetraxylopteris. This does not in reality indicate a basic similarity, but rather emphasizes a difference. The basic form of the xylem strand in Tetraxylopteris is retained in repeated branchings of the frond axes. In Tetrastichia, on the other hand, the cruciform primary xylem strand is a feature of the stem only. The petiolar trace broadens tangentially and divides to form two triangular traces from two angles of which branch pinna traces in two ranks. Thus, Tetrastichia bore bilaterally symmetrical fronds. Further details of the fronds are lacking since compressions have not been definitely associated with the petrified remains. It is clear, however, that they were distinctly different from the radially symmetrical fronds of Tetraxylopteris. It must be noted that the fronds in Tetrastichia arise in a decussate manner. Those of Tetraxylopteris occur on the stem in a spiral arrangement, but all branching in the fronds is decussate.
Stenokoleos (Hoskins and Cross, 1951) from the New Albany Shale is characterized by a cruciform primary xylem strand, and in this respect resembles both Tetrastichia and Tetraxylopteris. Since no information about its branching pattern is available at present, a definite conclusion about its possible relationship to these forms cannot be made.

Of the plants with which Tetraxylopteris may be closely related, Stenomyelon, Sphenoxylon and Tetrastichia are well established in the literature as pteridosperms, the two former being included in the Calamopityaceae, the latter in the Lyginopteridaceae. Aneurophyton and Palaeopitys, though still of uncertain affinity, seem also to be most closely related to the pteridosperms. All the Devonian plants considered, for which details of external morphology are known, lack well-defined leaves and bear instead branch systems terminating in bilobed, recurved, ultimate divisions (pinnules). These forms are Tetraxylopteris, Aneurophyton and Rhacophyton. This one common feature cannot be used as a criterion of taxonomic affinity because Rhacophyton is undoubtedly a coenopterid fern whereas the other genera show relationship with the pteridosperms. For reasons given previously Tetraxylopteris and Aneurophyton cannot be included within the Pteridospermae. The solid primary xylem strand, the large, terminal sporangia and the absence of completely differentiated leaves may indicate their origin from a psilophyte ancestor. These plants should be considered at present to be members of a relatively primitive complex, intermediate between the Psilophytales and Pteridospermales from which such forms as Stenomyelon, Sphenoxylon and Tetrastichia might have evolved. Aneurophyton has previously been considered to be an intermediate form linking the Psilophytales and Filicales (true ferns) (Hirmer, 1938; Høeg, 1942). Høeg erected a new order, Protopteridiales, in which he included Svalbardia, Protopteridium, Aneurophyton, Eospermatopteris, Rhacophyton and Dimeripteris $(=$ Rhacophyton, Kräusel and Weyland, 1941). Zimmermann (1938) had previously suggested a similar name, Protopteridales, for an order to include forms such as Protopteridium and Aphyllopteris which have poorly differentiated lateral organs and of which little is known about anatomical structure.

It is clear that Aneurophyton and Tetraxylopteris show much closer taxonomic affinity with the pteridosperms than with the coenopterids or true ferns. Aneurophyton must therefore be taken out of the Protopteridiales of Hoeg and, with Tetraxyl. opteris, included in a new order. The ordinal name, Aneurophytales, is selected for this intermediate group, the members of which show some psilopsid, some fern and some gymnospermous characters. The order is defined as follows:

Aneurophytales.-Plants with major axes 
which bear complex branch systems (fronds) which terminate in bilobed, recurved ultimate divisions (pinnules); fronds radially symmetrical. Where known, primary xylem is a lobed protostelic strand, the form of which is repeated in all orders of branching except ultimate divisions; protoxylems mesarch, numerous. Plants thought to be homosporous, with terminally borne, exannulate sporangia.

Throughout this paper the fronds of Tetraxylopteris have been considered to be homologous with true leaves. The major reason for this belief is that these structures, characterized by a distinctive decussate branching, are borne spirally on an axis which is believed to be the main axis (or stem) of the plant, and which probably branched sympodially. They are therefore distinguishable from the main axis by virtue of a difference in branching pattern, and since no other structures recognizable as photosynthetic organs are present it must be assumed that the fronds, or at least portions of them, served this function. A critical analysis of the fronds nevertheless shows that they are essentially cauline in nature. Their radial symmetry, the reconstitution of the shape of the primary xylem strand, and the pre sence of large amounts of secondary xylem and phlorm in some axes are all cauline features.

Bower (1884) presented evidence which indicated that the leaves of ferns and cycads evolved by gradual specialization from an undiff mentiated system of dichotomously branched axes. From a primitive dichotomous system he conceived of the evolution of a monopodial system by a stronger development of one half of the dichotomy thus forcing the other branch into a lateral posi'inn. Bower stated further that the concept of the leaf as a modified branch system could also be applied to the higher groups of plants. This concept has subsequently been supported and expanded by many workers and has led to the formulation of the so-called "telome theory" of Zimmermann (for historical literature and recent reviews of this theory, see Zimmermann, 1952; Wilson, 1953).

The fronds of Tetraxylopteris, which exhibit many cauline features, and yet are leaf-like in that they are organs sharply differentiated from the stem of the plant and probably photosynthetic in function, give strong support to Bower's hypothesis that the megaphyllous leaf has evolved from a branch system. One might further conclude that these fronds, because of their radial symmetry, represent a relatively primitive stage in the evolution of the leaf.

The secondary phloem of Tetraxylopteris is of considerable interest since it represents the second reported occurrence of this tissue in a Devonian plant. The only other well-authenticated occur- rence of this tissue in a Devonian plant is that of Callixylon (Penhallow, 1900; Arnold, 1930). The secondary phloem of Tetraxylopteris differs most markedly from that of Callixylon in containing elongate sclerenchymatous elements. Esau et al. (1953) suggested that the most primitive sieve element might be merely a physiologically specialized parenchyma cell. It is thus conceivable to the writer that the most primitive secondary phloem tissue was probably composed of morphologically relatively uniform parenchyma cells. If this is true, the complex phloem tissue of Tetrax. ylopteris may represent a considerable evolutionary advance - it is certainly more specialized than that of Callixylon-and even though occurring in a Devonian plant should probably not be considered to represent a very primitive type. To recognize that the secondary phloem of Tetraxylopteris is more specialized than that of Callixylon does not necessarily indicate that Tetraxylopteris is a more highly evolved form than Callixylon. It indicates rather to the writer that trends in the evolution of a tissue may be established at different times and proceed at different rates in different groups.

Throughout the history of paleobotanical study in New York it has been customary to assign newly found but incomplete specimens to genera already in the literature. Because most fossils are incomplete to a greater or lesser degree this custom has resulted in a number of "catch-all" genera each held together by at least one morphological feature. Arnold (1941) discussed this problem in respect to Psilophyton. It arises again in the case of fossils that when intact have recurved ultimate divisions on a system of branching axes. Fragments of such fronds may be merely ultimate divisions, ultimate pinnae or rachises, etc. Such specimens in recent years have been assigned to several genera including Aneurophyton and Aphyl lopteris. Leclercq's redefinition of Rhacophyton (1951), Kräusel and Weyland's (1941) investigation of Rhacophyton incertum ( $R$. condrusorum of Stockmans, 1948) from West Virginia and now the writer's establishment of a new genus based on abundant well-preserved specimens make it clear that incomplete (fragmentary) specimens may be impossible to name accurately because of similarities between these genera.

It is impossible to overestimate the importance of concentrating research on extensively preserved fossils, of finding petrified portions in axes of plants preserved mainly as compressions, and of recognizing that the possession of some common features does not necessarily indicate generic identity. The common features of many of the plants here discussed (Tetraxylopteris, Aneurophyton, Rhacophyton): recurved ultimate divisions, a system of branching axes in place of well-defined leaves and nearly identical secondary xylem (in 
Aneurophyton and Tetraxylopteris ${ }^{3}$ ) indicates that many fragmentary fossils should be treated as incertae sedis until they can be known sufficiently well to be fitted unhesitatingly into an existing generic category. Possibly, of course, a fuller knowledge would result in another new genus. The richness of the Devonian flora is a good sign that other plants probably existed. Therefore, it seems unwise to clutter up good genera with specifically unidentifiable fragments despite the natural desire to categorize everything that is found.

\section{SUMMARY}

A new Upper Devonian genus, Tetraxylopteris schmidtii, based on a large collection of specimens. from two localities in eastern New York, is described and illustrated. The specimens are compressions which have portions of some axes structurally preserved in iron pyrite. Thus internal structure as well as external morphology of the plant are described. The plant parts preserved consist of stems to which are attached spirally arranged branch systems (fronds) that are con. sidered to be homologous with leaves. The sterile fronds consist of a monopodial axis, the rachis, and three lesser orders of axes, the axes of the third order being bilobed ultimate divisions. All branching is opposite to sub-opposite with pairs of branches in alternating planes, i.e., decussate. The fertile fronds bear large, terminal, exannulate sporangia in their apical portions. Branching in the fertile fronds is probably identical to that of the sterile fronds except that the axes of the second order in the sporangiferous portion might be two-

${ }^{3}$ Other forms with secondary xylem essentially identical in known characters to these two are Sphenoxylon, Palaeopitys and Tetrastichia. Arnold (1940) emphasized that this secondary xylem, rather than indicating a group of related plants, "should be regarded as an early generalized type occurring among the large assmblage of primitive
Paleozoic forms ..." ranked. Both primary and secondary tissues are well-preserved and are described in detail. The primary xylem strand where known is cruciform in all axes except the ultimate divisions. Tetraxyl. opteris is compared with similar Devonian and Lower Carboniferous genera. It is probably most closely related to some members of the Calamopityaceae. The genus is not included in the Pteridospermales however because its characteristics indicate, rather, that it is probably an intermediate form between the psilopsids and pteridosperms. A new order, Aneurophytales, is erected to include Tetraxylopteris and Aneurophyton. The writer believes that the structure of the fronds supports Bower's (1884) hypothesis of the origin of the leaf from a branch system. The well-preserved secondary phloem is a relatively complex tissue and indicates to the writer that trends of evolution within a tissue may be established very early. This would seem to indicate also that the rate of evolution of a tissue can be very different from the rate of evolution of the plant as a whole. This is the second report of secondary phloem in a Devonian plant. Many Upper Devonian plant fossils preserved primarily as compressions show similar characteristics of external morphology. It is em. phasized that the presence of one or two common characters does not necessarily indicate generic identity although there has been a tendency in the past to classify some fossil plants on this basis. A thorough study of the external form combined with a knowledge of the anatomical structure enables the paleobotanist to classify fossil forms with a greater degree of accuracy than if based solely on external morphology. Information about anatomy although generally neglected can frequently be obtained from segments of pyritized axes often associated with compression specimens.

Department of Botany,

UNIVERSITY OF Michigan, Ann Arbor, Michigan

\section{LITERATURE CITED}

AndRews, H. N. 1940. On stelar anatomy of pteridosperms, with particular reference to the secondary wood. Ann. Missouri Bot. Gard. 27: 51-119.

Annold, C. A. 1930. Bark structure of Callixylon. Bot. Gaz. 90: 427-431.

1939. Observations on fossil plants from the Devonian of eastern North America. IV. Plant remains from the Catskill Delta deposits of northern Pennsylvania and southern New York. Contrib. Mus. Paleont. Univ. Michigan 5: 271-313.

1940. Structure and relationships of some Middle Devonian plants from western New York. Amer. Jour. Bot. 27 : 57-63.

- 1941. Psilophyton and Aneurophyton in the Devonian of eastern North America. Chron. Bot. 6: 375-376.

1947. An introduction to paleobotany. McGrawHill Book Co., Inc. New York.
Baxter, R. W. 1952. The coal-age flora of Kansas. II. On the relationships among the genera Etapteris, Scleropteris and Botrychioxylon. Amer. Jour. Bot. 39: 263-274.

BECK, C. B. 1955. A technique for obtaining polished surfaces of sections of pyritized plant fossils. Bull. Torrey Bot. Club 82: 286-291.

Bower, F. O. 1884. On the comparative morphology of the leaf in the vascular cryptogams and gymno. sperms. Phil. Trans. Roy. Soc. London 175: 565615.

1908. The origin of a land flora. MacMillan and Co., Ltd. London.

Chadwick, G. H. 1935. Summary of Upper Devonian stratigraphy. Amer. Midl. Nat. 16: 857-862.

Cooper, G. A., C. Butts, K. E. Caster, G. H. Chadwick, W. Goldring, E. M. Kindle, E. Kirk, C. W. Merriam, F. M. Swartz, P. S. Warren, A. S. Warthin, 
AND B. Willard. 1942. Correlation of the Devonian sedimentary formation of North America. Bull. Geol. Soc. Amer. 53: 1729-1794.

Darrah, W. C. 1941. The coenopterid ferns in American coal balls. Amer. Midl. Nat. 25 : 233-269.

Esau, K., V. I. Cheadle, and E. M. Gifford, JR. 1953. Comparative structure and possible trends of specialization of the phloem. Amer. Jour. Bot. 40: 9-19.

Goldrinc, W. 1924. The Upper Devonian forest of seed ferns in eastern New York. New York State Mus. Bull. 251 : 50-72.

Gordon, W. T. 1938. On Tetrastichia bupatides: A Carboniferous pteridosperm from East Lothian. Trans. Roy Soc. Edinburgh 59: 351-370.

Hirmer, M. 1938. Pteridophyta incertae sedis. In VerDoorn, Manual of Pteridology. The Hague.

HøEG, O. A. 1942. The Downtonian and Devonian flora of Spitzbergen. Norges Svalbard-og Ishavs-undersøkelser 83: 1-228.

Kidston, R., and D. T. Gwynne-Vaughan. 1912. On the Carboniferous flora of Berwickshire. Pt. I. Steno. myelon tuedianum Kidst. Trans. Roy. Soc. Edinburgh 48: 263-271.

- and W. H. Lang. 1923. On Palaeopitys Milleri M'Nab. Trans. Roy. Soc. Edinburgh 53: 409-417.

Kräusiel, R., and H. Weyland. 1923. Beiträge zur Kenntnis der Devonflora. I. Senckenbergiana 5: 154-184.

—, AND — . 1929. Beiträge zur Kenntnis der Devonflora. III. Abh. Sencken. Natur. Gesell. 41: $315-360$.

, AND - 1. 1935. Pflanzenreste aus dem Devon. IX. Ein Stamm von Eospermatopteris-Bau aus dem Mitteldevon des Kirberges, Elberfeld. Senckenbergiana 17: 9-20.

, AND - - 1941. Pflanzenreste aus dem Devon von Nord-America. II. Die Oberdevonischen Floren von Elkins, West-Virginien, und Perry, Maine, mit Berücksichtigung einiger Stücke von der ChaleurBai, Canada. Palaeontographica 86B : 3-78.

Leclero, S. 1940. Contribution à l'étude de la flore du
Dévonien de Belgique. Acad. Roy. Belgique 12: $1-65$.

1951. Étude morphologique et anatomique d'une fougère du Dévonien Supérieur. Le Rhacophyton zygopteroides nov. sp. Ann. Soc. Géol. Belgique 9: 1-62.

1954. An Upper Devonian zygopterid showing clepsydropsoid and etapteroid features. Amer. Jour. Bot. 41: $488-492$.

Penhallow, D. P. 1900. Notes on the North American species of Dadoxylon, with special reference to type material in the collections of the Peter Redpath Museum, McGill College. Trans. Roy. Soc. Canada 6: 51-97.

REad, C. B. 1937. The flora of the New Albany shale. Part 2. The Calamopityeae and their relationships. U.S.G.S. Prof. Paper 186-E: 81-104.

SAHNI, B. 1918. On the branching of the zygopteridean leaf, and its relation to the probable 'pinna' nature of Gyropteris sinuosa, Goeppert. Ann. Bot. 32: 369-379.

Stockmans, F. 1948. Végétaux du Dévonien Supérieur de la Belgique. Mem. Mus. Roy. Hist. Nat. Belgique 110: $1-85$

Thomas, D. E. 1935. A new species of Calamopitys from the American Devonian. Bot. Gaz. 97: 334-345.

WaLton, J. 1923. On a new method of investigating fossil plant impressions or incrustations. Ann. Bot. 37. 379-391.

1940. An introduction to the study of fossil plants. A. \& C. Black. London.

Willard, B. 1936. Continental Upper Devonian of northeastern Pennsylvania. Bull. Geol. Soc. Amer. 47: 565-608.

1939. The Devonian of Pennsylvania. Penn. Geol. Sur., Ser. 4, Bull. G19. Harrisburg.

WiLson, C. L. 1953. The telome theory. Bot. Rev. 19: 417-437.

Zimmermand, W. 1938. Phylogenie. In Verdoorn, Manual of Pteridology. The Hague. 1952. Main results of the "Telome Theory." The Paleobotanist 1: 456-470. 